\title{
Maja Žvorc
}

Independent researcher

\section{Herculean Allegory at the Čakovec Old Castle: Commissioner and Context}

\author{
Original scientific paper - Izvorni znanstveni rad \\ Received - Primljen 27. 6. 2017. \\ UDK 7.046.1:75.052(497.5Čakovec)
}

\begin{abstract}
Summary
The Museum of Medimurje in Čakovec, situated within the Old Castle Palace, holds an easel painting depicting the demigod Heracles and goddess Athena fighting the Nemean lion, surrounded by personifications and putti. The painting represents a copy of a fresco that was once painted across the ceiling of a monumental staircase that led to the palace's upper floors. Both the staircase and the ceiling painting were demolished in the mid- $19^{\text {th }}$ century, when the palace was adapted for use as a sugar refinery. The stairwell was built during the second quarter of the $18^{\text {th }}$ century by the then Čakovec estate owner, Countess Anna Maria Althann (1689-1755), who wanted to turn the derelict
\end{abstract}

palace into a representative Baroque residence. According to historical sources, Countess Althann, lady-in-waiting at Emperor Charles VI's (r. 1711-1740) court, commissioned the ceiling painting in order to commemorate the occasion when she - assisted by Countess Eleonore Batthyány (1672-1741) and Prince Eugene of Savoy (1663-1736) dissuaded the Emperor from equalizing the Kingdom of Hungary with other Habsburg hereditary lands in order to ensure the right of succession to a female dynasty member. The article discusses the context of the painting's commission, its iconography, allegorical interpretation, comparative examples, and possible models.

Keywords: Althann family, Čakovec Old Castle, ceiling painting, allegory, Anton Maria Konrath, Charles VI, Pragmatic Sanction

An allegorical easel painting depicting the demigod Heracles and goddess Athena fighting off the Nemean lion (Fig. 1) is currently on permanent display at the Museum of Medimurje in Čakovec. ${ }^{1}$ The museum is located within the Old Castle Palace, which served as a residence for many noble families throughout history, most notably the Zrinski (1546-1691), the Althann (1720-1791), and the Festetics (1791-1923). The painting was executed in 1797 by Anton Maria Konrath, who signed his work in the lower right corner of the painting. ${ }^{2}$ According to Károly Zrínyi (1905), the painting represents a copy of a fresco that was once painted across the ceiling of a representative staircase that led to the palace's upper floors. ${ }^{3}$ Both the ceiling painting and the staircase date from the period when the Cakovec estate was property of the Althann family, and they were both demolished in the mid- $19^{\text {th }}$ century, when the palace was adapted for use as a sugar refinery. ${ }^{4}$ Konrath's canvas, which represents so far the only known visual evidence of the original appearance of the ceiling painting, has not yet been fully researched. Art historians who have touched upon the topic - Andela Horvat, Vladimir Marković, and Petar Puhmajer - have mostly discussed the ceiling painting and its easel copy in a few lines, without studying them in detail..$^{5}$ Surprisingly, the subject has sparked more interest among historians Károly Zrínyi Rudolf Horvat, and Ivana Jukić - who have been mostly preoccupied with the historical context of the original ceiling painting's commission and its symbolism, ${ }^{6}$ which will be elaborated further in the text.

The Althann family came into the possession of the Čakovec Old Castle in 1720, when Emperor Charles VI (Vienna, 1685-1740; crowned the King of Hungary and Croatia as Charles III) gave the estate to Count Michael Johann Althann III (Jaroslavice, 1679 - Vienna, 1722), his close friend and confidant. ${ }^{7}$ According to the historical sources, Count Althann, who was the royal chamberlain, privy councillor, and chief equerry, received the estate from the emperor as a gift for his service in the War of the Spanish Succession (1701-1714). However, according to some less official contemporary documents, the count also received the estate because he defended the honour of the emperor's mistress, Spanish Marquise Anna Maria Josepha Pignatelli de Belriguardo (Alcudia, 1689 - Vienna, 1755), by marrying 


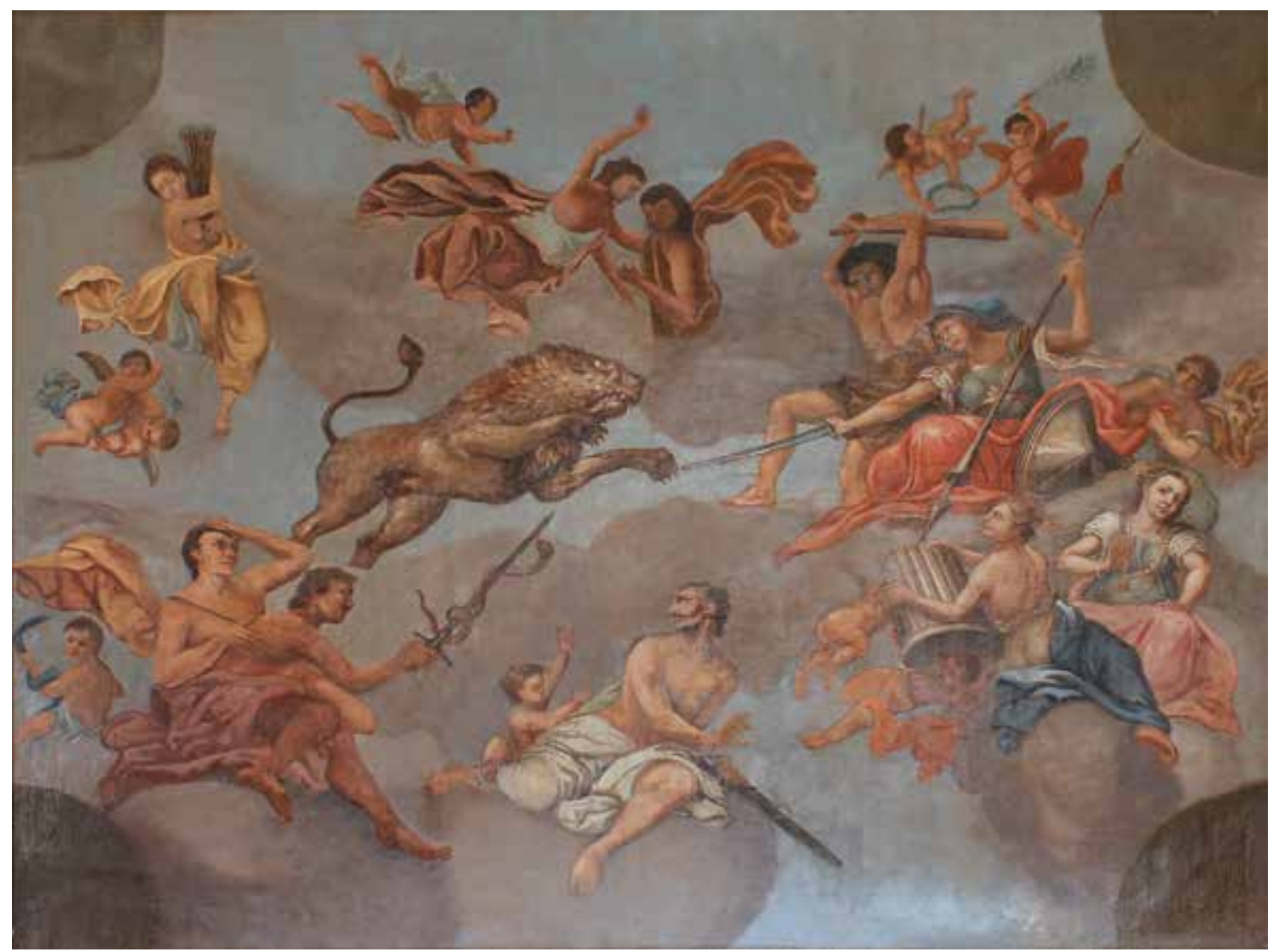

1. Anton Maria Konrath, Allegory, 1797, oil on canvas, Čakovec, Museum of Međimurje (photo: M. Žvorc) Anton Maria Konrath, Alegorija, 1797., ulje na platnu, Čakovec, Muzej Medimurja

her after she was impregnated by the emperor. ${ }^{8}$ Two years after he was officially declared the owner of the Čakovec Old Castle, Count Michael Johann Althann died in 1722, leaving his wife as the legal heiress to the estate. After her husband's death, Countess Althann moved to Vienna, where she lived at the court as a lady-in-waiting, but she frequently visited Čakovec, usually in the company of the emperor himself. ${ }^{9}$

Soon after receiving the Čakovec estate, the Althanns began renovating the Old Castle Palace and its surrounding fortifications, which were in a terrible condition due to decades of neglect. ${ }^{10}$ Although researchers disagree on the question in what year the renovation works began - some believe the Althanns began to renovate immediately after they received the estate in $1720,{ }^{11}$ while others believe the renovation began only after the great earthquake of $1738,{ }^{12}$ which caused additional damage to the complex - the Althann family thoroughly renovated the Old Castle, turning its derelict four-winged palace into a representative Baroque residence. The renovation lasted until 1743 and included: reconstructing the upper two floors and raising the second floor ceiling construction; renovating the main and innercourtyard façades; demolishing the old tower that stood above the palace entrance and building a new one above the entrance bastion; and - most importantly for this article building a representative staircase in the north-east wing of the palace. ${ }^{13}$ On the basis of stylistic features of the main and inner-courtyard façades as well as historical data, researchers believe the Althanns hired for their renovation an architect of Italian origin but of Viennese provenance, Anton Erhard Martinelli (Vienna, 1681-1747), a close associate of Joseph Emanuel Fischer von Erlach. ${ }^{14}$

The position and elevation of the staircase can be reconstructed on the basis of two sets of architectural drawings. The first set consists of floor plans of all four palace storeys that were made by the geodesist Joseph Lippay between 1796 and $1797,{ }^{15}$ and the second of a floor plan and cross-section of the staircase that were made by the engineer János Szajdenswartz in 1821 (Fig. 2). ${ }^{16}$ The three-flight staircase was situated in the north-east wing of the palace, and it connected all four palace storeys. The first flight rose from the arcade porch alongside the inner wall up to the first floor. At the mezzanine level, it was divided by a landing, from which one could access the rooms on that storey. The remaining two flights connected the first with the second floor, leading to a long hallway. The stairway walls were decorated with architectural elements made in stucco, such as pilasters that narrow towards the base, characteristic of the Austrian $\mathrm{Ba}$ roque ${ }^{17}$ and an ornamented semicircular niche. Above the staircase rose a cavetto or mirror vault that was decorated with the aforementioned allegorical painting. The staircase was demolished in the mid- $19^{\text {th }}$ century, when the then 


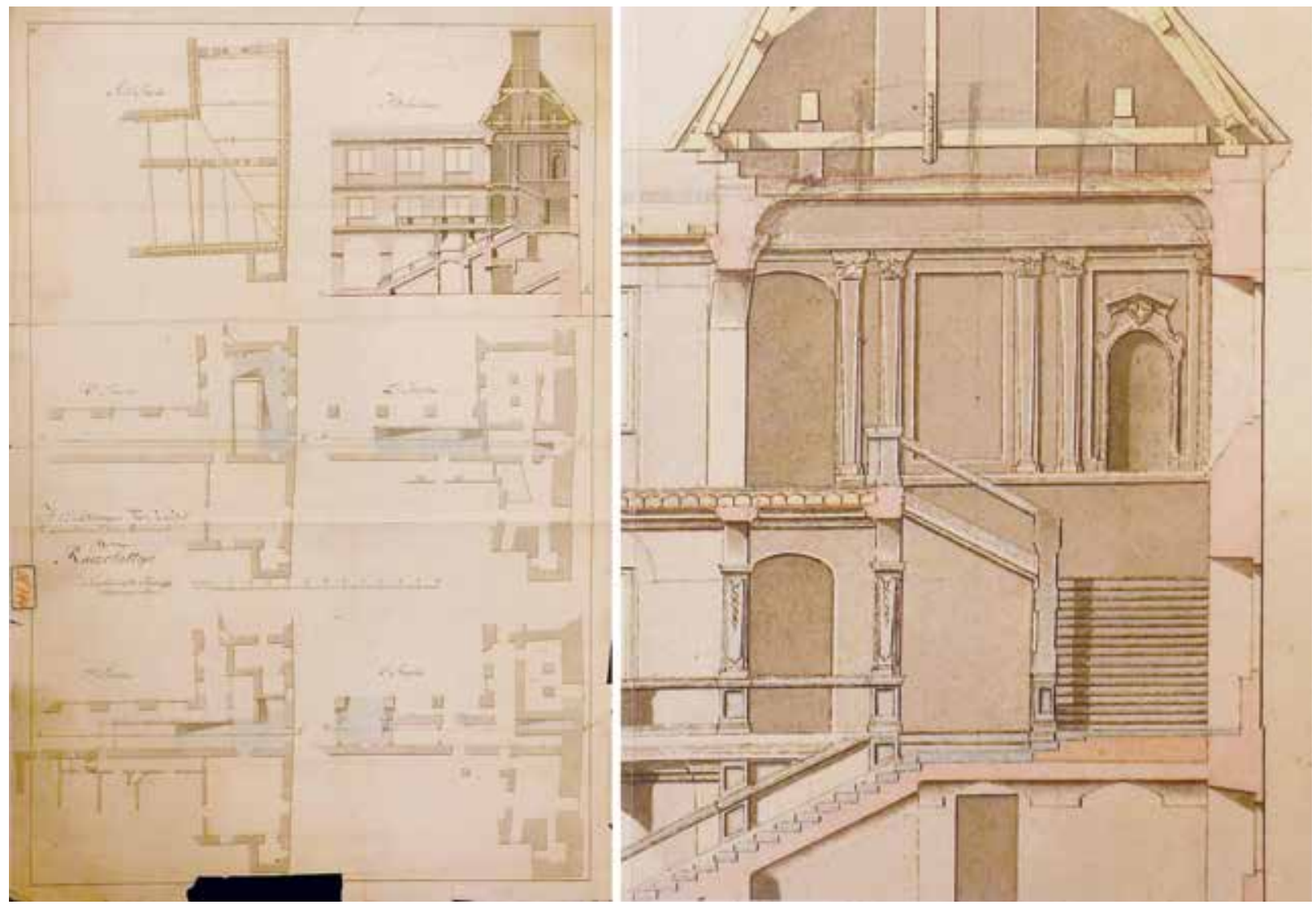

2. Janós Szajdenswartz, Plans of the representative staircase and its cross-section (detail), 1821, Budapest, Magyar Nemzeti Levéltár (source: P. PUHMAJER, note 5)

Janós Szajdenswartz, Nacrt reprezentativnoga stubišta i njegov presjek

owner of the Čakovec estate, György Festetics II (Vienna, 1815-1883), adapted the northern part of the palace and the surrounding fortifications for a sugar refinery, which was in operation for only over a decade (1858-1870). ${ }^{18}$ The only visible trace of a once representative staircase that has been preserved until today is a niche with stucco decoration, which has been incorporated into one of the museum rooms on the second floor.

The appearance of the ceiling painting can be reconstructed on the basis of the preserved canvas, which is stored and displayed at the museum. The easel painting shows a blue sky laden with personifications and figures from Greco-Roman mythology. Goddess Athena (Roman: Minerva) is shown in armour, with a sword in her right and a spear in her left hand, fighting off a lion. Demigod Heracles (Roman: Hercules) is coming to her aid, holding a club with both arms raised high above his head. When shown together in allegorical depictions, Heracles and Athena represent strength: Heracles symbolises the physical and Athena the moral strength, i.e. wisdom..$^{19}$ Above the pair hover two putti holding a laurel wreath and a palm branch, symbols of victory. ${ }^{20}$ Right from Athena, a female figure of dark complexion is shown clutching the goddess's skirt, pulling it over Athena's shield placed beside her. Below them, two other female figures are depicted (Fig. 3). To the left, showing her back to the viewer, there is a personification of fortitude recognisable by a column, ${ }^{21}$ which she is holding with the help of two putti. To the right, there is a personification of honour, dressed in rich garments and wearing pearls around her wrist and in her hair. ${ }^{22}$ Around her neck, she is wearing the chain of the Order of the Golden Fleece, the insignia of a prestigious chivalric order whose membership was reserved solely for European Roman Catholic royalty and nobility. ${ }^{23}$ Count Michael Johann III and his son Michael Johann IV were both admitted to the Order (the former in 1712 and the latter in 1739).

In the lower left corner of the picture, an infant is shown strangling a snake wrapped around its arm. The figure is reminiscent of the myth of infant Heracles, when the jealous goddess Hera, provoked by her husband's unfaithfulness, sent two snakes to kill him. ${ }^{24} \mathrm{~A}$ group of two men is depicted on the infant's left, one of whom is holding a sword with a snake coiled around it, pointing the blade towards the lion. In Cesare Ripa's Iconologia, a sword with a coiled snake is an attribute of fortitude: the sword symbolises bodily strength and the snake prudence of the spirit. ${ }^{25}$ However, in the Čakovec canvas, a male figure is shown instead of a female, and he is lacking other attributes characteristic of fortezza. Next to the described group, there sits a man clad in white drapery. Gripping an empty scabbard, he is recoiling from the lion in fear. 


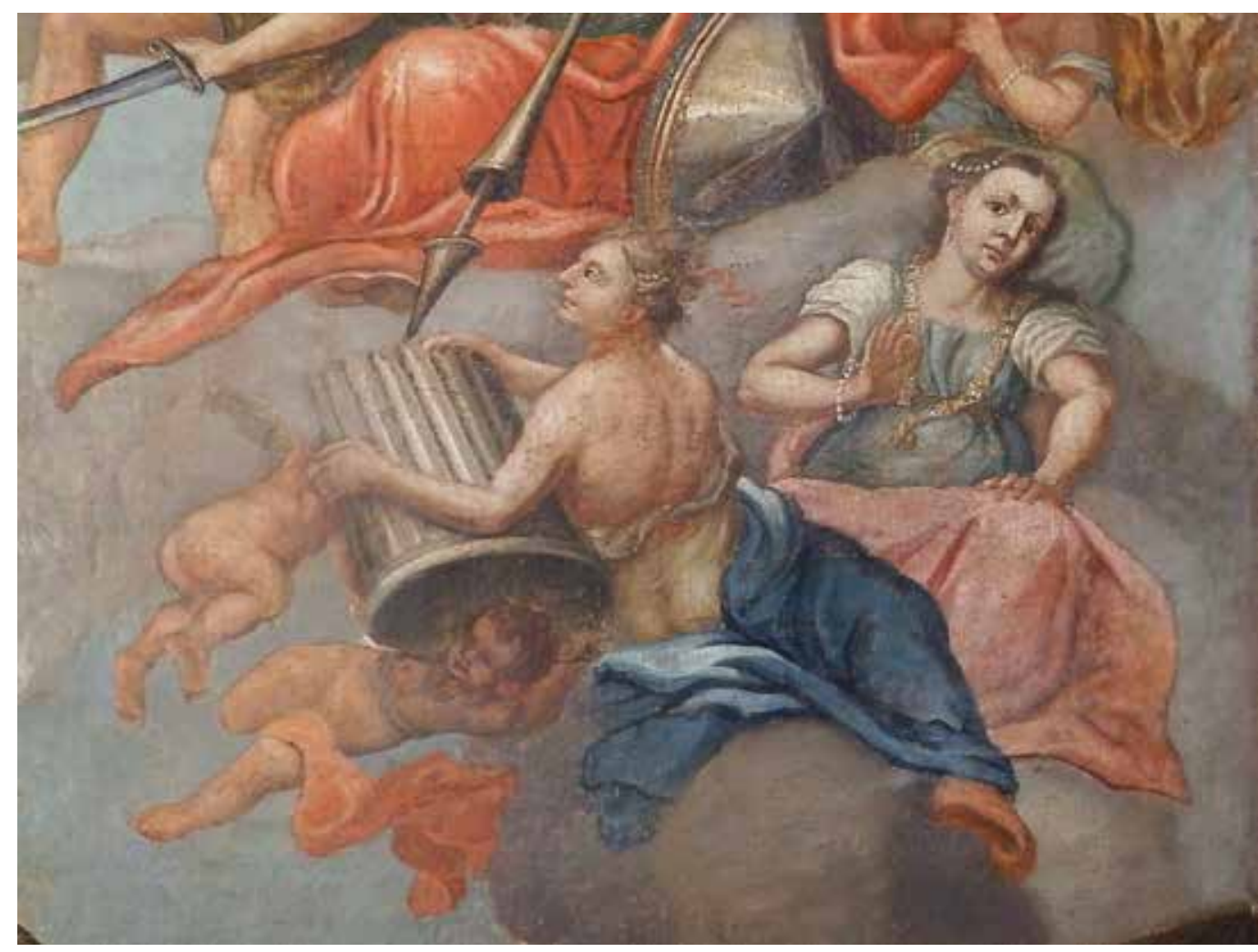

3. Detail of the allegory: personifications of fortitude and honour (photo: M. Žvorc)

Detalj alegorije: personifikacije jakosti i časti

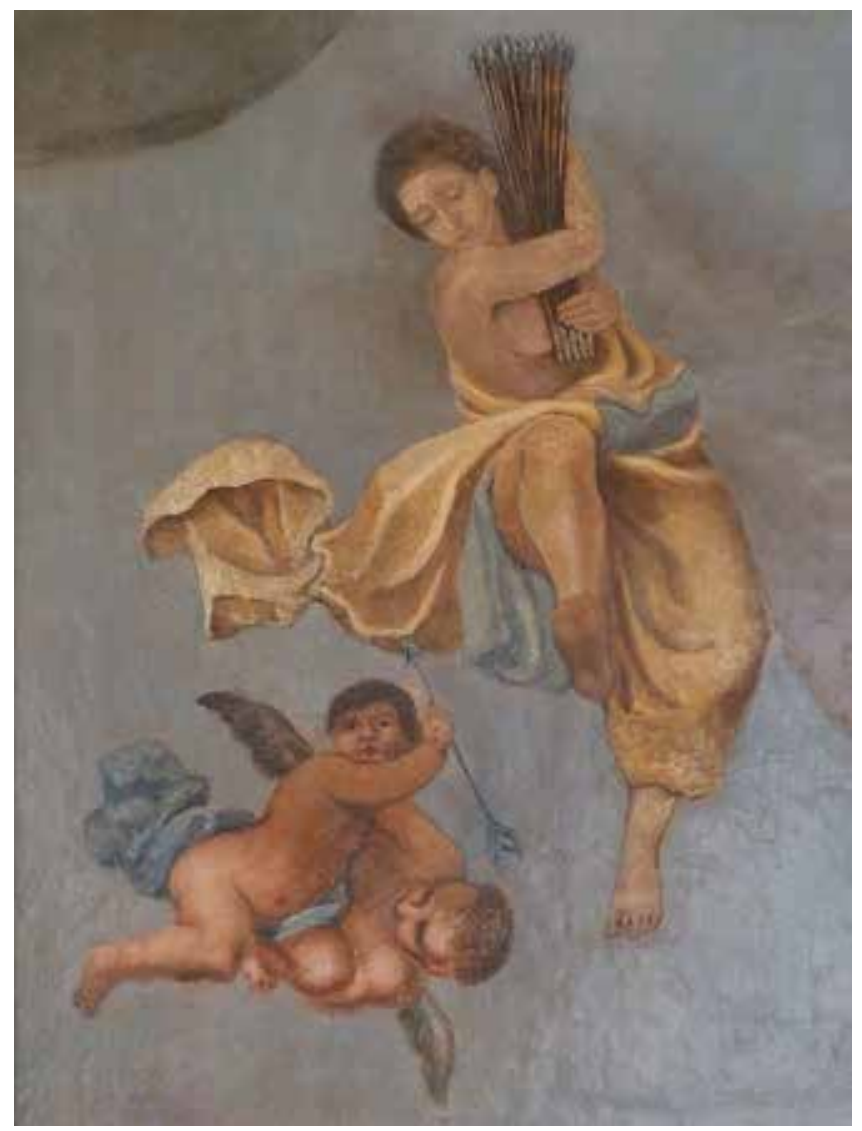

In the upper left corner of the picture, a female figure is depicted accompanied by two putti (Fig. 4). She is holding a bundle of arrows resembling fasces, which defines her as the personification of concord. ${ }^{26}$ To the right, hovering above the lion, there is a couple of - what at first seems to be - male figures. If we examine one of the earliest reproductions of Konrath's painting, which was published in Károly Zrínyi's monograph on Cakovec in 1905 (Fig. 5), ${ }^{27}$ we can clearly see that it is actually a woman and a man (Fig. 6). The pair's symbolic meaning is not easily discernible due to the lack of attributes. If we observe the reproduction more closely, we can see that the entire upper part of the canvas has been painted over, most probably in a less successful attempt to restore the painting. Apart from the aforementioned pair, several other figures have been repainted: the personification of concord with two putti, as well as Heracles, Athena, and their accompanying putti (Fig. 7). So far only one more work has been attributed to the same author who signed the described painting, Anton Maria Konrath. The work in question is The Adoration of the Shepherds from the Franciscan Monastery of Saint Nicholas the Bishop in Čakovec. ${ }^{28}$ Although Konrath painted in a style characteristic of the High Baroque, which

4. Detail of the allegory: personification of concord with two putti (photo: M. Žvorc)

Detalj alegorije: personifikacija sloge i dva putta 


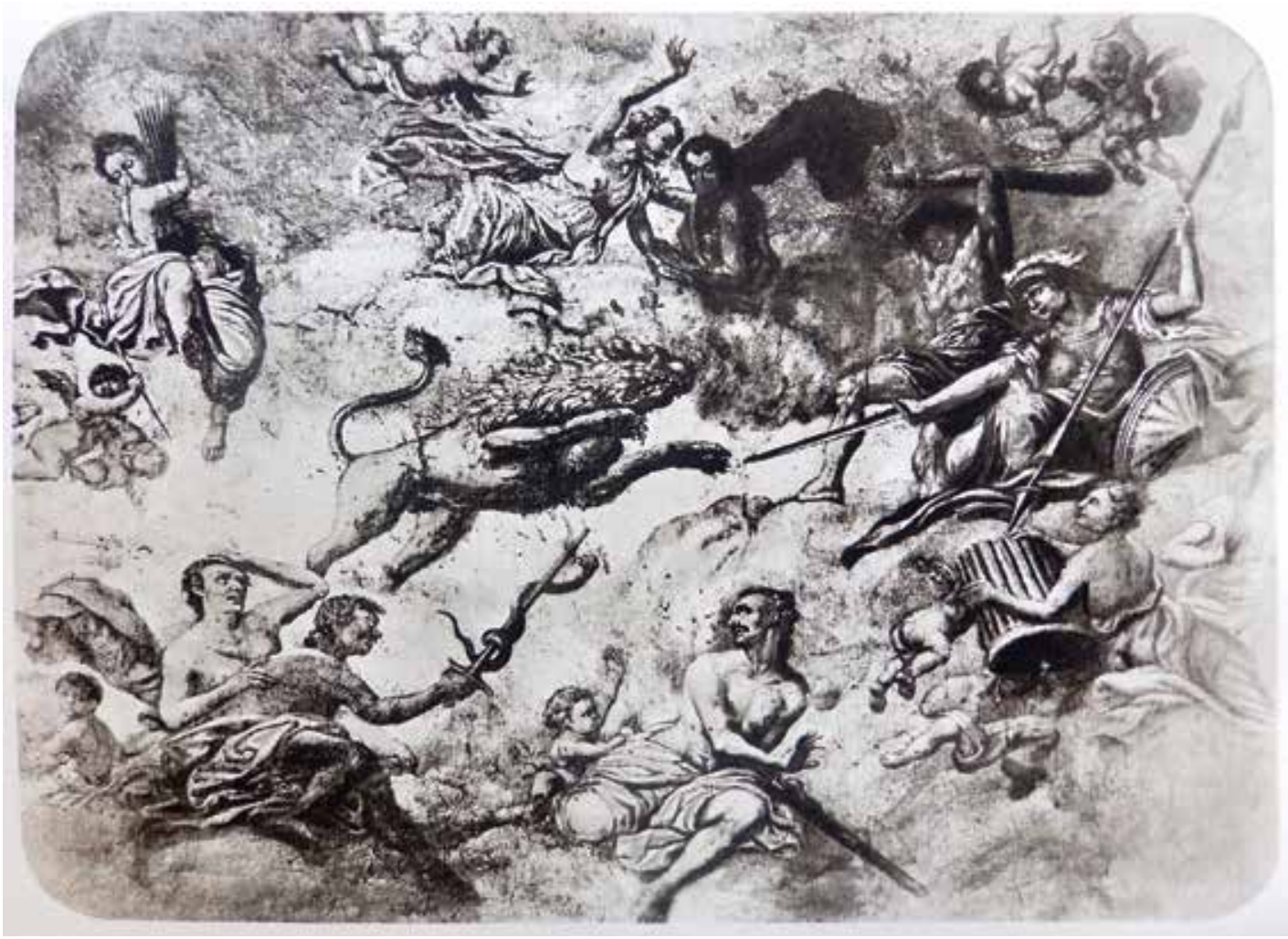

5. Reproduction of the allegory published in Károly Zrínyi’s monograph on Čakovec (source: K. ZRÍNYI, note 3) Reprodukcija alegorije objavljena u Zrínyijevoj monografiji grada Čakovca

at the end of the $18^{\text {th }}$ century made him rather eclectic, ${ }^{29}$ his skills far surpassed those displayed by the person who tried to retouch the canvas exhibited at the museum.

In the Baroque period, halls and stairwells were - as the most representative rooms in a residence - often decorated with images and scenes from classical mythology. Commissioners often used the mythological context to promote real, contemporary figures and events, as mythology provided them with means to surpass the restraints of passing human life and reach for the eternity inherent to myths. ${ }^{30}$ According to Károly Zríny, the ceiling painting from the Čakovec Old Castle Palace appears to be no exception. In his opinion, the painting's meaning can be tied to a specific event that took place in $1722 .^{31}$ Apart from the already mentioned Countess Anna Maria Althann and Emperor Charles VI, the event has two more protagonists: Countess

6. Comparison of the painting's former and present state: female and male figures

Usporedba prethodnog i sadašnjeg stanja slike: ženski $i$ muški lik
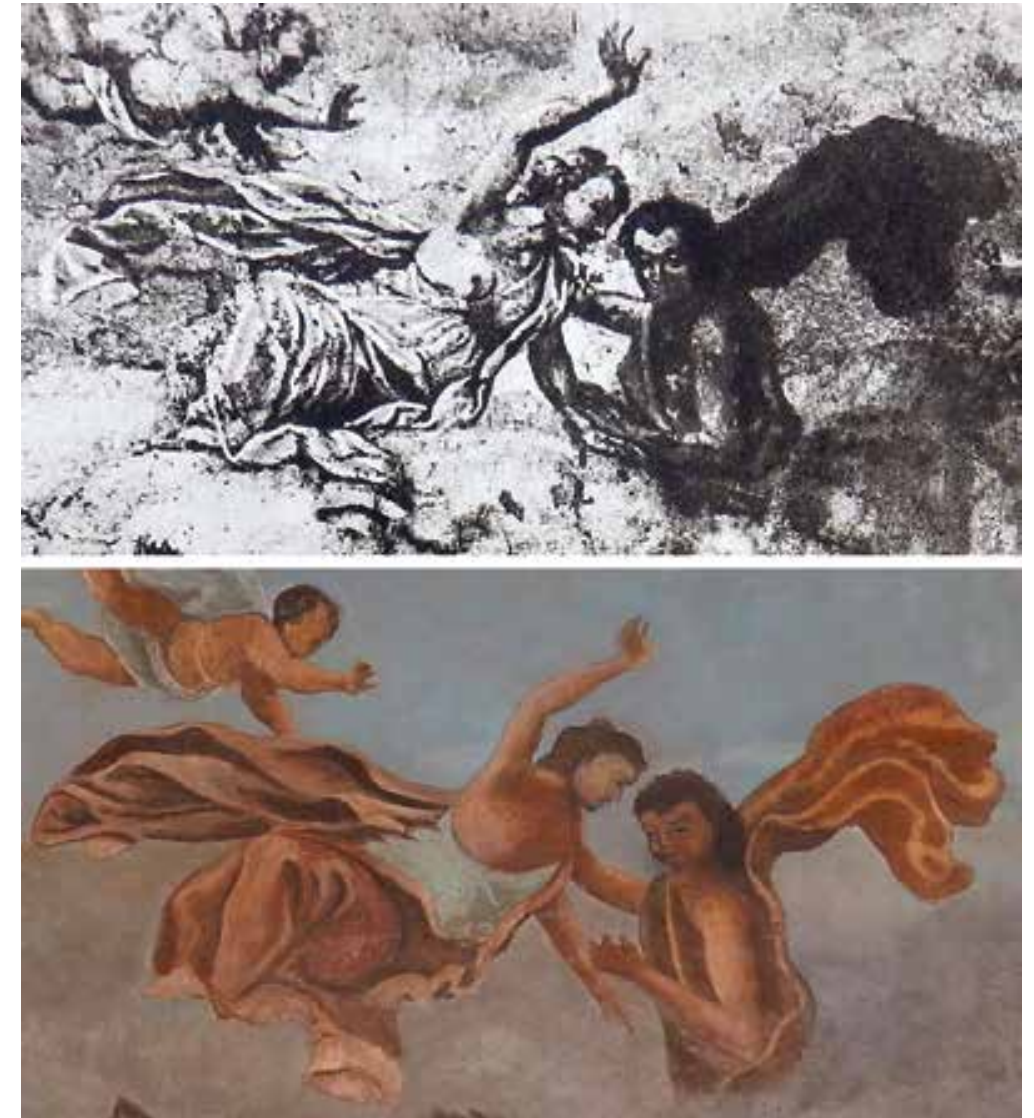

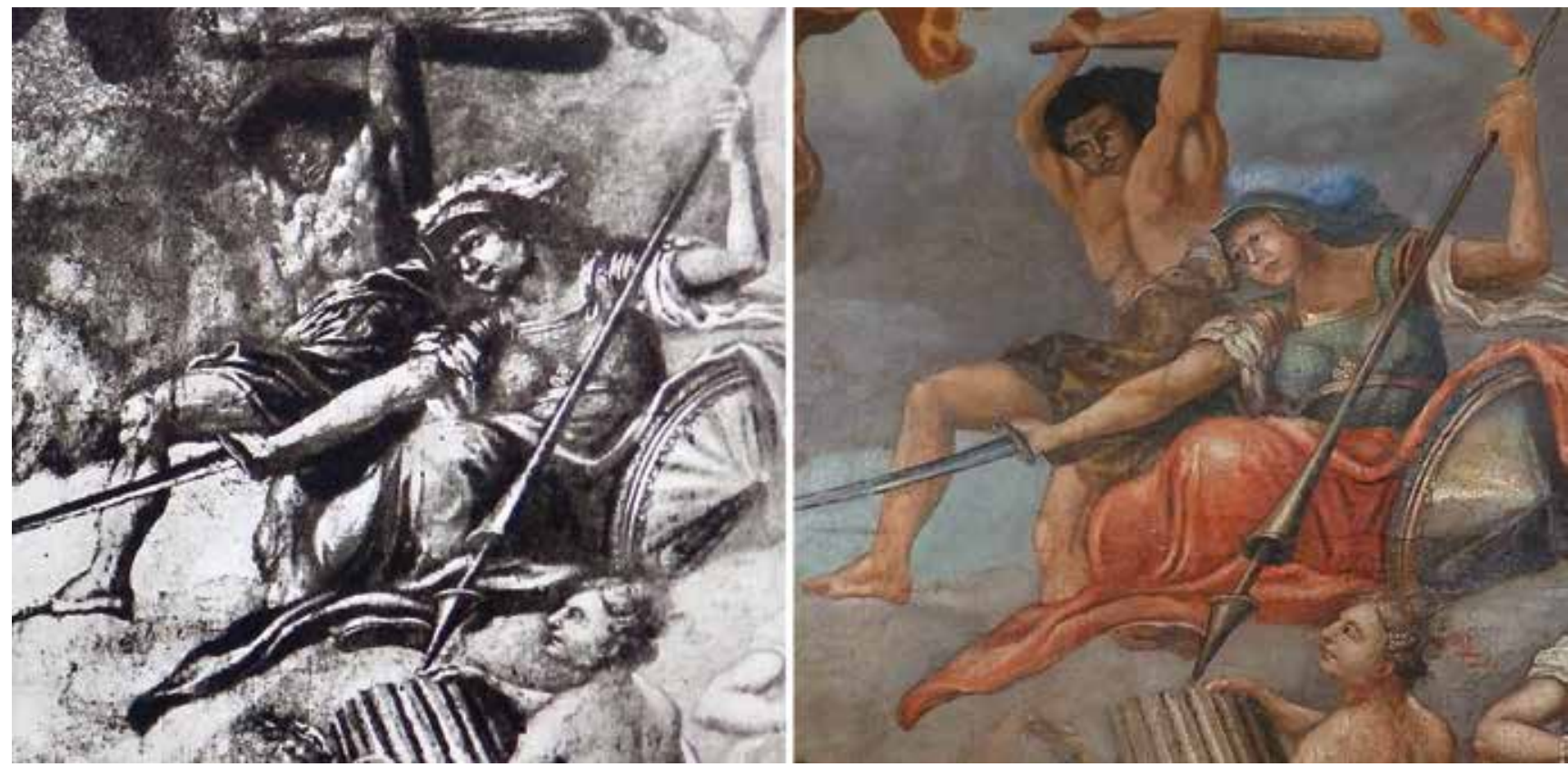

7. Comparison of the painting's former and present state: Heracles and Athena

Usporedba prethodnog i sadašnjeg stanja slike: Heraklo i Atena

Eleonore Magdalena Ursula Batthyány born Strattmann (Pfalz?, 1672 - Vienna, 1741), who was Anna Maria's close friend and lady-in-waiting at the Viennese court, and the famous general and President of the Imperial War Council, Prince Eugene of Savoy (Paris, 1663 - Vienna, 1736). According to Zrínyi, Countess Batthyány learned from Prince of Savoy, with whom she had a close relationship, that Emperor Charles VI had sent his troops to different parts of the Hungarian Kingdom as a precautionary measure in his attempt to abolish the Hungarian constitution and equalize the Kingdom with other Habsburg hereditary lands, all in order to ensure the right of succession to a female dynasty member. ${ }^{32}$ After learning of the emperor's plan, Eleonore Batthyány sent Anna Maria Althann a letter asking her to intervene and dissuade him from his intention, knowing the two shared a special relationship. According to one version of the story, Countess Althann managed to dissuade the emperor by herself, while according to another she received help from Prince Eugene of Savoy. ${ }^{33}$ Regardless of which version we examine, the outcome is similar: with combined efforts, the two countesses and the prince managed to preserve the Hungarian constitution. To commemorate the event, Countess Althann commissioned the making of a ceiling painting at her family's palace in Čakovec, Međimurje, which at the time was part of the Hungarian Kingdom. ${ }^{34}$

On the basis of the described event, Zrínyi gave his own account of whom the figures in the painting represent. According to his opinion, the female figure with the column represents Anna Maria Althann, who is holding the dilapidated pieces of the Hungarian constitution and is trying to put them back together. ${ }^{35}$ The figure of Athena represents Eleonore Batthyány, and that of Heracles Eugene of Savoy, who are fighting with joined forces against the lion.
The animal symbolises the force attacking the Hungarian constitution, i.e. the emperor. Zrínyi interprets the woman wearing the chain of Order of the Golden Fleece and the man below the lion gripping an empty scabbard as the subjugated Hungarian nation, which is shrinking in fear from the attack on its sovereignty and is unable to defend itself on its own. ${ }^{36}$

A contemporary historian Rudolf Horvat based his reading of the painting more or less on Zrínyi's interpretation. ${ }^{37} \mathrm{He}$ similarly interpreted the figure of Heracles as Prince Eugene of Savoy, but he switched the roles of the countesses. According to his opinion, the personification of fortitude represents the "frightened" Countess Batthyány, while Athena symbolises Countess Althann, who is fighting against the attack on the Croatian and Hungarian constitution. Horvat widened Zrínyi's interpretation of the female figure with the Golden Fleece chain from the personification of Hungary to the personification of the entire Pannonia in order to include both the Croatian and Hungarian Kingdoms. It should be noted that during the 1900s Čakovec and Međimurje were still under the Hungarian administration. ${ }^{38}$ Both Zrínyi and Horvat published their work during a politically tumultuous period and were influenced by different political ideas, especially the ones concerning the question of Međimurje's political, national, and ethnic affiliation. Zrínyi and Horvat had opposing views on the topic: whereas the former strongly believed that Međimurje demographically, historically, and culturally belonged to the Hungarian Kingdom, the latter claimed its rightful place was within the Kingdom of Croatia and Slavonia.

The question of the allegory's interpretation has not been dealt with in detail by Croatian researchers since Zrínyi and Horvat. It has been only recently that Ivana Jukić re-analysed the context of the painting's commission, trying to establish 
the extent to which personal relations among dignitaries within the Habsburg Monarchy - especially those between women - influenced the forming of state politics. ${ }^{39}$ According to her opinion, the trio - Anna Maria Althann, Eleonore Batthyány, and Eugene of Savoy - did not act primarily in defence of the Hungarian constitution, but rather in defence of Charles VI's Pragmatic Sanction of 1713 (Sanctio Pragmatica), an edict with which the Emperor wanted to ensure that his daughters could inherit his imperial rights. At the Bratislava Council in 1687, the Croatian and Hungarian Kingdoms recognised the Habsburg dynasty as their hereditary kings. ${ }^{40}$ However, according to the law's third article, in case the dynasty remained without a male heir, Croatian and Hungarian nobility had the right to elect a new king. At the time when the episode depicted in the allegory took place (1722), the Croatian Kingdom and Transylvania had already recognised the Pragmatic Sanction - the former in 1712, the latter in 1722 - but not the Hungarian Kingdom. ${ }^{41}$ In Ivana Jukić's opinion, Countesses Althann and Batthány and Prince of Savoy dissuaded Emperor Charles VI from violently forcing the Kingdom of Hungary to accept the idea of hereditary rights in a female line and persuaded him to allow Eugene of Savoy to obtain the consent of Hungarian nobility in a diplomatic way, an endeavour in which the prince succeeded already the following year (1723) with the help of Esterházy and Pálffy families. ${ }^{42}$ Accordingly, Jukić has interpreted the figure of the lion as the part of the Hungarian nobility who opposed accepting the Pragmatic Sanction, and the man sitting helplessly under the animal as the other part of the nobility, who saw their future with the Habsburgs. ${ }^{43}$ According to her opinion, Athena and Heracles represent Eleonore Batthyány and Eugene of Savoy, who are fighting off the opposition, while the pair hovering above the lion can be interpreted as Countess Anna Maria Althann and Emperor Charles VI himself.

As it can be observed, Zrínyi, Horvat, and Jukić all agree that sometime after 1722 Countess Althann commissioned the making of a fresco that would represent her and the two of her associates as the emperor's confidants who had influence in forming the imperial politics. However, Zrínyi's and Horvat's reading of the painting differs from Jukić's, primarily regarding the question in whose favour the countesses and the prince were acting - that of the Hungarian nation or the Emperor. Considering the fact that Anna Maria Althann, Eleonore Batthyány, and Eugene of Savoy were all close associates and courtiers of the emperor, Jukićs viewpoint - that the trio acted in his interest rather than that of the Hungarian people - seems more probable. The iconographic reading of figures in the canvas can only confirm that the scene depicts a fight between virtues and vice. The two main personifications that are represented are wisdom, embodied by Athena, and strength, embodied by Heracles, which are two of the four cardinal virtues required for a moral life. Their victory over vice, symbolised by the lion, is ensured as two putti are holding a laurel wreath and a palm branch over Athena's and Heracles' heads. The importance of strength of both body and mind is enhanced by the personification of fortitude and symbol of a snake coiled around a sword, which is held by one of the male figures. Virtues are supported by two more personifications, those of concord and honour. Without a written concetto or additional attributes such as a coat-of-arms, it is difficult to state with certainty whether particular figures in the picture were originally meant to be interpreted as real, historical figures. In his book, Zrínyi listed sources only for the event when Countesses Althann and Batthyány and Prince of Savoy helped to preserve the Hungarian constitution. ${ }^{44}$ However, in his interpretation of the painting's meaning - on which both Horvat and Jukić based their own - Zrínyi relied primarily on his notion of whom the figures in the picture might represent, not on concrete historical documents or sources.

If for the moment we put the question of the painting's interpretation aside and observe it topic-wise within a broader context, we will notice that its Herculean theme fits in the trends of the contemporary European visual arts. During the early modern period, Heracles was one of the most frequently depicted figures from classical antiquity. ${ }^{45}$ Carrying the role of exemplum virtutis, he was often employed in both religious and moral allegories. He did not represent only "physical male or military potency," but also "the generosity and strength of the mind." ${ }^{46}$ As he presented the virtue of both body and mind, he was one of the most important models for rulers, princes, and high dignitaries in the early modern period. ${ }^{47}$

The practice of using Heracles' figure as means of selfidentification and promotion reached its peak in the last third of the $17^{\text {th }}$ and the first third of the $18^{\text {th }}$ centuries, ending with the reign of Charles VI (1711-1740). ${ }^{48}$ Even the emperor himself drew heavily on the idea of Heracles as a virtuous leader in both war and peace, comparing himself to the ancient hero, of whom he professed to be a descendant. ${ }^{49}$ One such example is his full-length sculpture portraying him as Hercules musarum at the Vienna Imperial Library (Hofbibliothek), which is surrounded by sculptures of Charles' ancestors and topped by a fresco glorifying the fame and honour of the House of Habsburgs, most primarily that of its last male representative, i.e. Emperor Charles himself. ${ }^{50}$ Similarly, Prince Eugene of Savoy commissioned in the latter part of his life a sculpture of his own apotheosis symbolising his eternal fame, in which he is shown wearing a lion's skin - a clear reference to Heracles..$^{51}$ Even the Althann family drew on the same tradition in their visual representation. At the family chateau in Vranov nad Dyjí, Michael Johann Althann II (Vienna, 1643 - ?, 1722), father of Michael Johann III, constructed a monumental Hall of Ancestors (Czech: Sál predki̊; 1687-1695) and decorated it with sculptures of his predecessors and an allegorical fresco with figures from classical mythology - including several scenes from the life of Heracles - which glorified the name, the past, and the merits of the Althann family. ${ }^{52}$

As the paragon of virtue, Heracles was also often employed in allegorical depictions carrying a moral message. One such example can be found at the Benedictine abbey of Melk in Lower Austria. The ceiling of the abbey's Marble Hall (Marmorsaal), which was conceived as a feast and dining hall for 


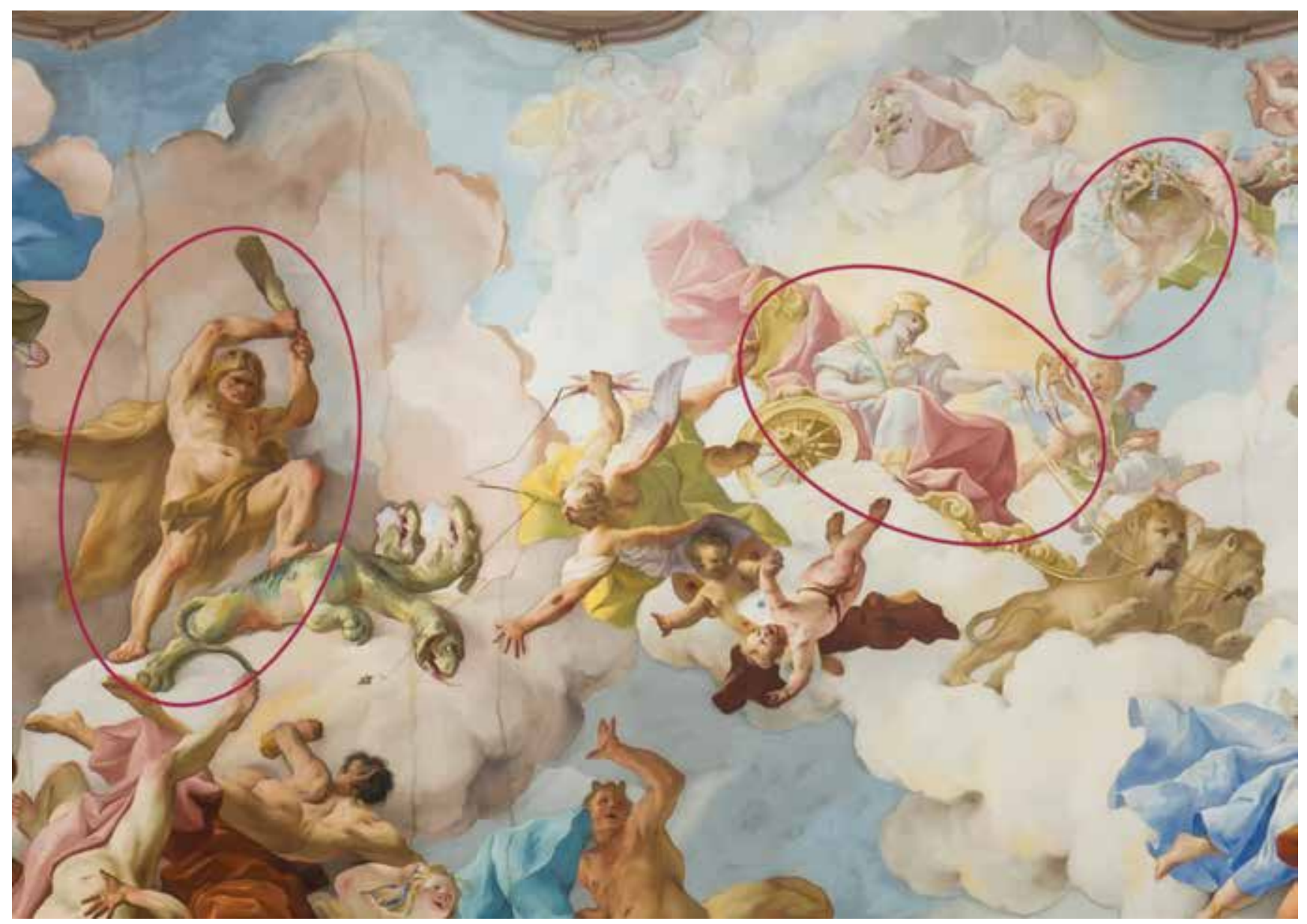

8. Paul Troger, Marble Hall (Marmorsaal) ceiling painting, 1731, Melk Benedictine Abbey (source: Wikipedia) Paul Troger, slika na svodu Mramorne dvorane (Marmorsaal), 1731., Melk, benediktinska opatija

distinguished guests - most notably members of the royal court - is adorned by a fresco showing Heracles fighting Cerberus in the presence of Athena, who is riding a chariot drawn by two lions (Fig. 8). They are surrounded by putti and figures representing vices and virtues, which indicate the fresco's symbolic reading: the struggle and triumph of virtue over vice, good over evil..$^{53}$ The fresco was painted by a well-known Austrian artist, Paul Troger (Monguelfo, 1698 - Vienna, 1762), in 1731. If we compare the Melk fresco with the Čakovec easel painting, we will notice particular similarities in the impostation of the two main mythological figures: that of Heracles with his arms raised high above his head forming a characteristic rectangular shape, and that of seated Athena with a slight inclination of the head following the movement of her outstretched arm and parted legs with drapery stretched between them. Similarities can also be found in the impostation of a third figure, namely the putto holding a flower basket in Melk, i.e. a column in the Čakovec painting (Fig. 3), with its right leg bent far behind.

After completing his work at the Melk Abbey, Troger was commissioned by the Cistercian monks of the Zwettl Abbey to paint the ceiling of their library (1732-1733). He decorated the ceiling with five individual scenes that once again included Heracles and the personifications of vices and virtues. ${ }^{54}$
Their meaning roughly mirrored the meaning of the Melk fresco: "Those who wish to attain wisdom must eradicate vices through diligence and work, and plant the virtues in themselves." ${ }^{55}$ In one of the scenes, Heracles is again shown fighting Cerberus, while the personifications of constancy and strength hover above him (Fig. 9). His triumph over the monster is ensured as a personification of victory is holding a laurel wreath over his head. The impostation of Heracles' figure is very similar to the one in the Čakovec painting perhaps even more than the one from the Melk Abbey - with the same characteristic rectangular placement of the arms and the leg shown closer to the viewer raised high and bent in the knee. The described parallels from Melk and Zwettl suggest that the artist who painted the ceiling of the representative staircase at Čakovec used similar models as Troger.

Another comparative example can be found even nearer, in Donje Oroslavje, in the region of Hrvatsko Zagorje. The main hall of the Oroslavje Vojković-Vojkffy Mansion is decorated with a ceiling painting of Heracles' Apotheosis (Fig. 10), which was executed by an unknown author at the end of the $18^{\text {th }}$ century, after the construction of the building was completed. ${ }^{56}$ Similarities between the paintings from Donje Oroslavje and Čakovec can once again be observed in the impostation of Heracles and the lion, which suggests that the authors 


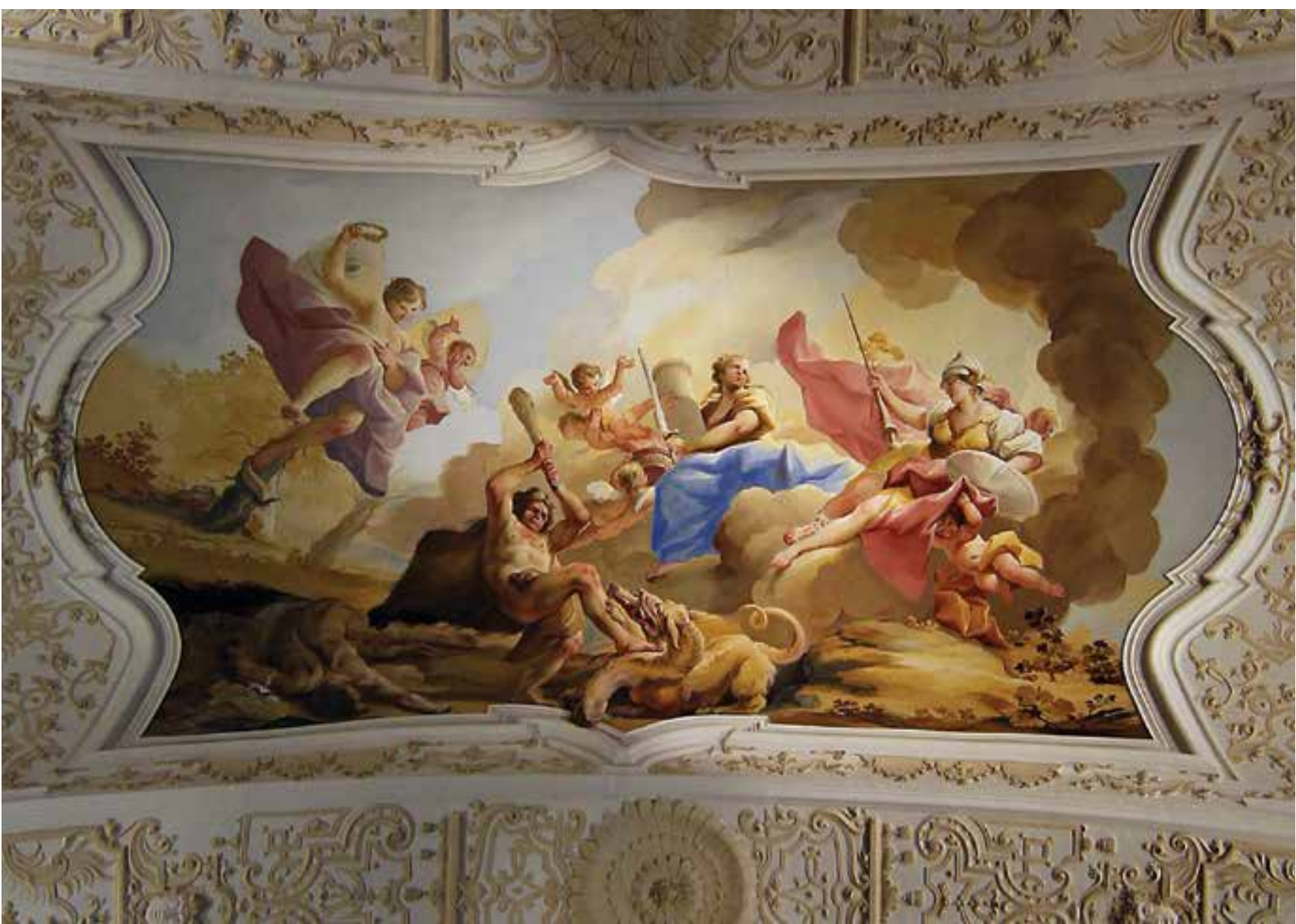

9. Paul Troger, Library ceiling painting, detail, 1733, Zwettl Cistercian Abbey (source: Wikipedia)

Paul Troger, slika na svodu knjižnice, detalj, 1733., Zwettl, cistercitska opatija

used the same models. This notion is strengthened by an interesting curiosity: both lions were painted with two left paws. Mirjana RepanićBraun has connected the painting from Donje Oroslavje with the ceiling fresco at the Attems Castle in Slovenska Bistrica, Slovenia. The fresco also depicts Heracles' Apotheosis, and it was executed by Franz Ignaz Flurer (Augsburg, 1681 - Graz, 1742), the painter of Ignaz

10. Unknown painter, Heracles' Apotheosis, end of the $18^{\text {th }}$ century, Donje Oroslavje, VojkovićVojkffy Mansion (photo: Institute of Art History, Photo archive)

Neznani slikar, Heraklova apoteoza, kraj 18. stoljeća, Donje Oroslavje, Dvorac Vojković-Vojkffy

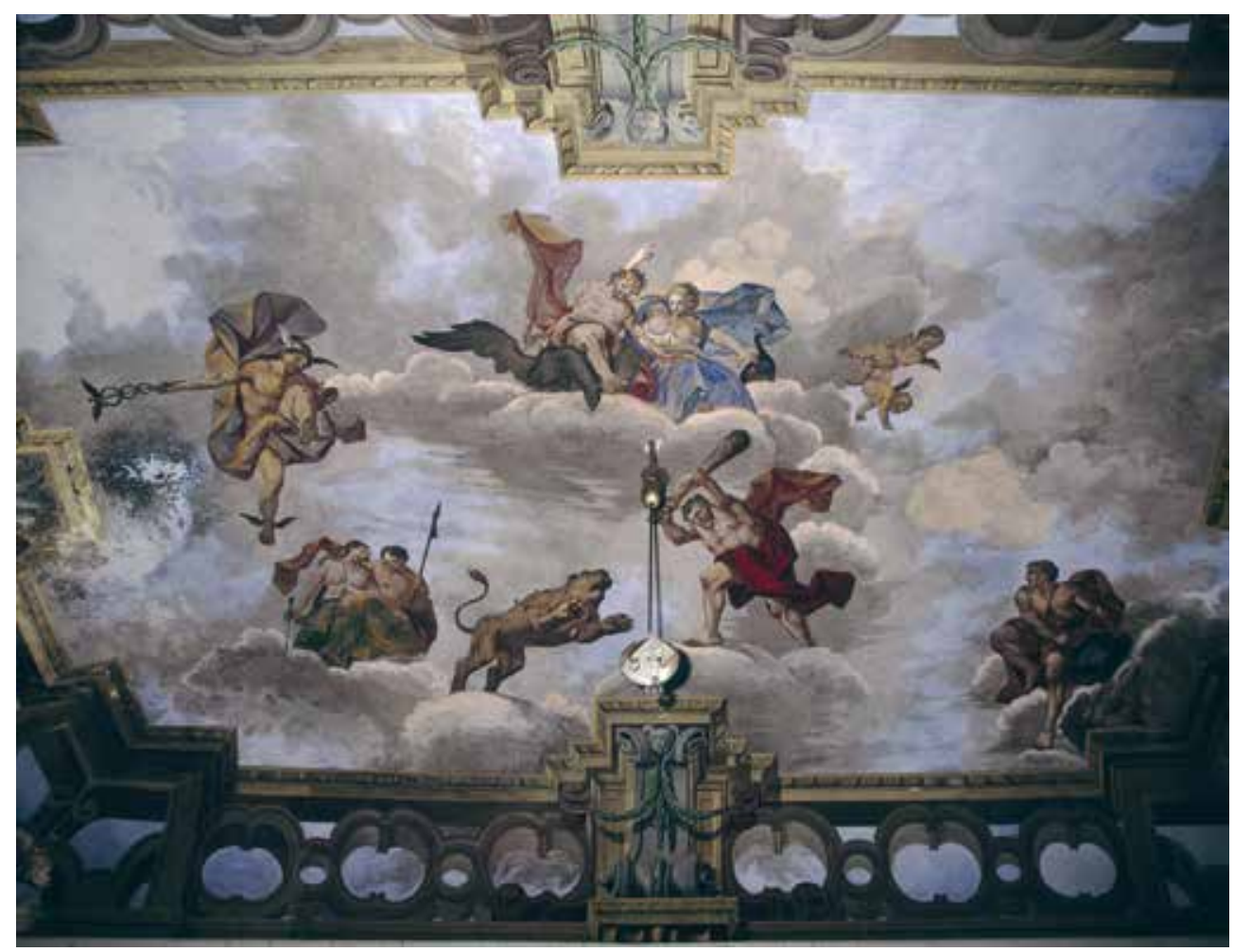




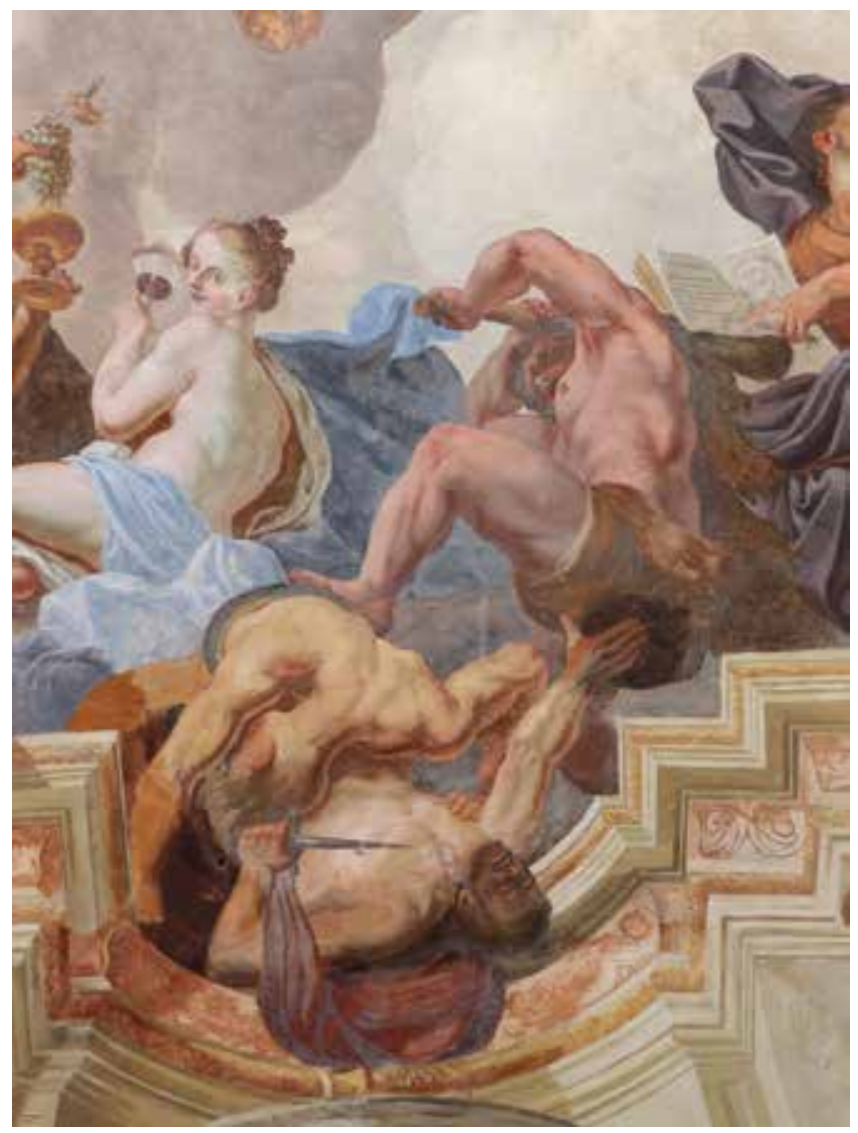

11. Johann Caspar Waginger, Allegory of the Five Senses, detail, ca. 1718, fresco, Brežice Castle (photo: M. Žvorc)

Johann Caspar Waginger, Alegorija pet osjetila, detalj, oko 1718., dvorac Brežice

Maria, Count of Attems (Ljubljana, 1652 - Graz, 1732). ${ }^{57}$ Apart from the mythological theme and basic compositional parallels (celestial background, the use of di sotto in sù), the example from Slovenska Bistrica shares few similarities with the painting from Čakovec.

However, there is another piece executed under the patronage of Count Attems that includes Heracles' figure similar to the one in Čakovec. The work in question is a ceiling painting decorating the representative staircase of Brežice Castle in Slovenia. It was executed by Johann Caspar Waginger (documented 1704-1718) around 1718, and it shows an allegory of the five senses. ${ }^{58}$ The sense of touch is represented by a figure of Heracles (Fig. 11), who is once again shown smiting his enemies with a club raised above his head, trampling their back with his leg raised high.

As the figures of Heracles from Čakovec, Melk, Zwettl, Donje Oroslavje, and Brežice all share impostational similarities, it is possible that their creators used similar models. The visual source might be found in London, at the Whitehall Palace. The palace was used as a residence by British monarchs from 1530 to 1698 , when it was heavily damaged by fire. One of the few buildings that have survived until today is the Banqueting House, the ceiling of which is adorned with vast canvases executed by Peter Paul Rubens (Siegen, 1577 - Antwerp, 1640). The paintings celebrate the life and government of

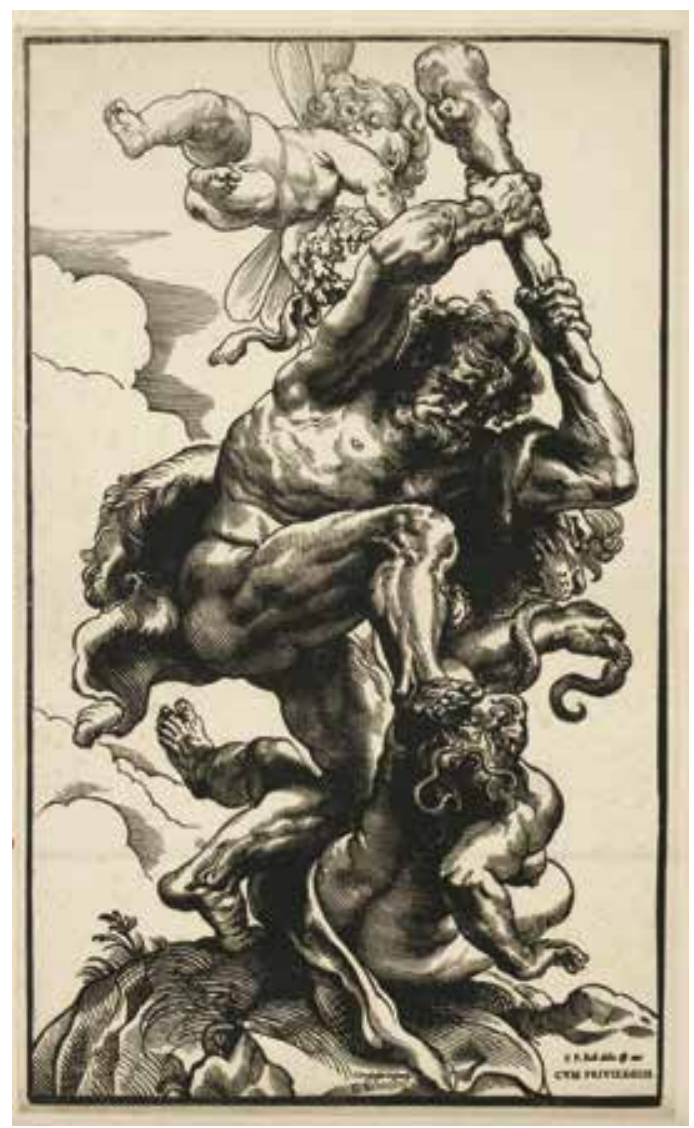

12. Christoffel Jegher, Hercules as a Heroic Virtue Overcoming Discord, ca. 1634-1636, woodcut, $603 \times 359 \mathrm{~mm}$, New York, The Metropolitan Museum of Art (source: https://www.pinterest.co.uk/ $\operatorname{pin} / 520376931913671763 /)$

Christoffel Jegher, Heraklo kao herojska vrlina nadvladava neslogu, oko 1634.-1636., drvorez, $603 \times 359 \mathrm{~mm}$, New York, The Metropolitan Museum of Art

Emperor James I (r. 1567-1625) and were commissioned by his son, Charles I, after his father's death. ${ }^{59}$ The central panel, showing the Emperor's apotheosis, is flanked by scenes from his life, while in the corners there are four ovals representing James' virtues. In one of the ovals, Heracles is shown overcoming discord, with distinct impostation that has been observed in previous examples: the rectangular placement of arms raised above his head and the strong step forward with his leg raised. A preparatory oil sketch has been preserved, which was adapted into an engraving (Fig. 12) by Christoffel Jegher (Antwerp, 1596-1652/3) under the supervision and official authority of Rubens himself. ${ }^{60}$ Interestingly, the picture of Heracles is the only image based on the Whitehall ceiling that Rubens allowed to be published, meaning that no other canvases from Whitehall have been made into engravings. The reason for Rubens' choice might lie in the fact that Heracles was the most recognizable as an exemplum virtutis and the easiest to translate to a more universal level, so the artists who wished to use this model could apply it in a variety of contexts. ${ }^{61}$ If we compare Rubens' work to the aforementioned ceiling paintings in Austria, Slovenia, and Croatia, we can assume that his composition served if not as an exact model, than at least as an inspiration for other 
images of Heracles. With the help of Jegher's engraving, Rubens' compositional solution circulated across Europe and was used by a variety of artists.

The corpus of early modern secular ceiling paintings in continental Croatia is modest. ${ }^{62}$ The ceiling painting from the Čakovec Old Castle Palace is one of its constituents that has been lost due to unfortunate circumstances. Luckily, with the help of Konrath's easel copy, we can reconstruct the appearance of the original painting and discuss its meaning. Thematically and compositionally, the Čakovec ceiling painting kept pace with other works in the contemporary European visual arts, with the main intention of promoting its commissioners as politically - although perhaps covertly - influential persons in the Habsburg Monarchy.

\section{Notes}

* Research for this paper has been fully supported by the Croatian Science Foundation's funding of the project 6827 Visual Arts and Communication of Power in the Early Modern Period (1450-1800): Historical Croatian Regions at the Crossroads of Central Europe and the Mediterranean. Its earlier version entitled "Venus of Čakovec, Minerva of Hungary and Hercules of Savoy: Allegory of Defence of Charles VI's Pragmatic Sanction" was presented at the International workshop Between Venice, Hungarian Kingdom and Habsburgs: State and Religious Iconography and the Places of its Dissemination during the Early Modern Period in Historical Croatian Territories (Zagreb, Institute of Art History, 2-3 June 2016), organized as part of the project and financed by the Croatian Science Foundation (HRZZ - Hrvatska zaklada za znanost).

1

Anton Maria Konrath, Allegory, 1797, oil on canvas, $190 \times 252$ cm, Čakovec, Museum of Međimurje, MMČ-7152.

2

The inscription reads: ANTON MARIA KONRATH / PINXIT 1797. The author signed his name and the date at the bottom of the column held by a female figure and a putto. The inscription has faded with time and is today barely visible.

3

KÁROLY ZRÍNYI, Csaktornya monografiája: a vár es város története s az 1901-iki népszamlalás, Csaktornya, 1905, 63. A Croatian translation of the book was published in 2005 to mark the $100^{\text {th }}$ year anniversary of the monograph's first publication. See: KÁROLY ZRÍNYI, Monografija grada Čakovca: povijest dvorca i grada: popis stanovništva iz 1901., Čakovec, 2005, 77.

4

KÁROLY ZRÍNYI (note 3, 1905), 66.

5

ANĐELA HORVAT, Spomenici arhitekture i likovnih umjetnosti u Medimurju [Architectural and visual arts' monuments in Međimurje], Zagreb, 1956, 30-31; VLADIMIR MARKOVIĆ, O baroknim dvorcima u Hrvatskoj (dvije skice) [On baroque mansions in Croatia (two sketches)], in: Radovi Instituta za povijest umjetnosti, 11 (1987), 143-157, 146-147; PETAR PUHMAJER, Čakovec: Stari grad - Novi dvor: povijesno-umjetnička studija [Čakovec: Old Castle - New Mansion, an art historical study], Zagreb, 2006, 35-36.

6

KÁROLY ZRÍNYI (note 3, 1905), 63-66; RUDOLF HORVAT, Kako su grofovi Althann stekli Medimurje [How the Counts of Althann acquired Međimurje], in: Hrvatska revija = Croatian review $=$ Kroatische Rundschau $=$ La revista croata: $\check{c}$ asopis Matice hrvatske, II/5 (1929), Zagreb, 334-336, 335-336; RUDOLF HORVAT, Poviest Međimurja [History of Međimurje], Čakovec, 1993, $3^{\text {rd }}$ edition ( $1^{\text {st }}$ in 1908), 199-200; IVANA JUKIĆ, Dvorske dame izvan Bečkoga dvora: ili kako su kreirale društveno-političko ozračje ugarsko-hrvatskoga ranonovovjekovnoga prostora [Court ladies outside of the Viennese court, or how they created the sociopolitical climate in the Hungarian-Croatian early modern space], in: Ascendere historiam: Zbornik u čast Milana Kruheka, (eds.) Marija Karbić, Hrvoje Kekez, Ana Novak and Zorislav Horvat, Zagreb, 2014, 301-314. Rudolf Horvat states that the allegory was executed in bas-relief, differently from other researchers who write that it was executed as a ceiling painting. As Horvat does not cite his source, we cannot know from where he got the information. See: RUDOLF HORVAT (note 6, 1929), 335; IDEM (note 6, 1993), 200. However, due to the fact that a copy of the original piece was executed in easel painting - and not in sculpture or graphic - and that there exist several comparative examples from contemporary European ceiling painting - to which we shall come further in the text - it seems more likely that the original piece was executed as a ceiling painting rather than a relief. In his study on the Čakovec Old Castle, Petar Puhmajer states that there were actually two artworks depicting a similar, allegorical theme: a bas-relief cut in stone and a ceiling painting. See: PETAR PUHMAJER (note 5), 35. Puhmajer took the information about the bas-relief from Rudolf Horvat, but considering the fact that Horvat claims the relief was - just as the ceiling painting - placed above the main staircase of the courtyard entrance and that it was destroyed during the 1850s, when the palace was adapted for a sugar refinery, we can deduce that there was only one, and not two allegorical depictions.

7

RUDOLF HORVAT (note 6, 1929), 334; IDEM (note 6, 1993), 198-199; VLADIMIR KALŠAN, Međimurska povijest [History of Međimurje], Čakovec, 2006, 162; VLADIMIR KALŠAN - JANKO KALŠAN, Međimurski biografski leksikon [Biographical lexicon of Međimurje], Čakovec, 2012, 12.

8

RUDOLF HORVAT (note 6, 1929), 334-335; IDEM (note 6, 1993), 198-199; VLADIMIR KALŠAN (note 7), 162, footnote 2.

\section{9}

KÁROLY ZRÍNYI (note 3, 1905), 63; RUDOLF HORVAT (note 6, 1929), 335; IDEM (note 6, 1993), 199; VLADIMIR KALŠAN (note 7), 164; IVANA JUKIĆ (note 6), 306.

10

After the death of Adam Zrinski ( $\uparrow 1691)$, the last family member to reside in Čakovec, during the following thirty years the estate belonged to the Hungarian Royal Chamber, Emperor Charles VI, 
and several individual owners, who all put little effort in maintaining the estate buildings. See: KÁROLY ZRÍNYI (note 3, 1905), 5960; VLADIMIR KALSAN (note 7), 136, 161. The poor state of the Čakovec Old Castle can be evidenced from its description written by Stephanus Jaszenski de Nagy Jeszen in 1720. The Latin transcription and Croatian translation of Jaszenski's description were first published by: DIANA SAMARŽIJA, Tvrđava Čakovec. Pronađen dokument za daljnje istraživanje tvrđave Čakovec [The Čakovec fortress: A newly discovered document], in: Vijesti muzealaca $i$ konzervatora Hrvatske, 2 (1973), 13-16. See also: PETAR PUHMAJER (note 5), 29-32, 78-80; IVAN SRŠA, Čakovec, Novi dvor, 2.: Izvještaj o rezultatima konzervatorsko-restauratorskih istraživanja žbukanih i bojenih slojeva na trima razinama (prizemlju, međukatu i katu) u jugoistočnom i jugozapadnom krilu palače u kompleksu Staroga grada u Čakovcu [Čakovec, Novi dvor, 2: Report on the results of conservation and restoration research on the plaster and paint layers on three levels (ground floor, mezzanine, and first floor) in the south-east and south-west wings of the Old Castle Palace in Čakovec], Zagreb, 2006, 263-264.

\section{1}

IVAN SRŠA (note 10), 264; IDEM, Palača u čakovečkom 'Starom gradu' za Althanna (Obnove u 18. stoljeću)" [Palace in the "Old Castle" of Čakovec in Althann's time ( $18^{\text {th }}$-century renovations)], in: Sic ars deprenditur arte: zbornik u čast Vladimira Markovića, (eds.) Sanja Cvetnić, Milan Pelc, and Daniel Premerl, Zagreb, 2009, 469-483, 471-472, 480; KATARINA HORVAT-LEVAJ, Barokna arhitektura [Baroque architecture], Zagreb, 2015, 565.

12

PETAR PUHMAJER (note 5), 33-34.

13

PETAR PUHMAJER (note 5), 34-37; IVAN SRŠA (note 10), 265-279; IDEM (note 11), 472-482; KATARINA HORVATLEVAJ (note 11), 567-569.

14

VLADIMIR MARKOVIĆ, Anton Erhard Martinelli - graditelj Althannovog dvorca u Čakovcu [Anton Erhard Martinelli - Architect of Althann's mansion in Čakovec], in: Radovi instituta za povijest umjetnosti, 1-2 (1972), 13-21, 16-19; PETAR PUHMAJER (note 5), 33; IVAN SRŠA (note 10), 265, 278; IDEM (note 11), 480; KATARINA HORVAT-LEVAJ (note 11), 565-568.

\section{5}

The plans were first published and interpreted by: IVY LENTIĆ KUGLI, Nekoliko planova Starog grada u Čakovcu [Several plans of the Čakovec Old Castle], in: Vijesti muzealaca $i$ konzervatora Hrvatske, 28/1 (1979), 23-31, 24-26. See also: PETAR PUHMAJER (note 5), 35; IVAN SRŠA (note 10), 267-268; IDEM (note 11), 475-476. All of the drawings are stored at the National Archives of Hungary, T - Tervtár, T Családi fondokból kiemelt tervek (1659-2000), T 3 Festetics család (1743-1941) (abbr. T 3 Fe. Csa.), T_3_No_263, T_3_No_265-267.

16

The drawing is stored at the National Archive of Hungary, T 3 Fe. Csa., T_3_No_349. Apart from the drawing, Szajdenswartz also made the elevation of the main and inner-courtyard facades. See: IVY LENTIĆ KUGLI (note 15), 26, 29; PETAR PUHMAJER (note 5), 36, 39-41; KATARINA HORVAT-LEVAJ (note 11), 567-568.

17

PETAR PUHMAJER (note 5), 36; KATARINA HORVAT-LEVAJ (note 11), 569.

18

KAROLY ZRÍNYI (note 3, 1905) 66; RUDOLF HORVAT (note 6, 1929), 336; IDEM (note 6, 1993), 200; VLADIMIR KALŠAN (note 7), 222; PETAR PUHMAJER (note 5), 36, 44; IVAN SRŠA (note 10), 308-309; IDEM, Stari grad Čakovec (1791.-1948.) [Čakovec Old Castle (1791-1948)], in: Kaj: časopis za književnost, umjetnost $i$ kulturu, XLIX/1-2 (2016), 61-79, 66. Zrínyi states that it was György Festetics II who commissioned the making of the ceiling painting's copy, just before he ordered the staircase to be demolished. This, however, cannot be true, since the easel copy is signed and dated 1797, at which time Festetics was not even born. The easel painting was most probably commissioned by György II’s grandfather, György I (Ság, 1755 - Keszthely, 1819), who bought the Čakovec estate from the Althanns in 1791.

19

JAMES HALL, Rječnik tema i simbola u umjetnosti [A dictionary of subjects and symbols in art], Zagreb, 1998, 108.

20

JAMES HALL (note 19), 183, 238.

21

CESARE RIPA, Iconologia, overo descrittione dell'imagini universali cavate dall' antichità et da altri luoghi da Cesare Ripa Perugino, opera non meno utile, che necessaria à Poeti, Pittori, Scultori, per rappresentare le virtù, vitij, affetti, et passioni humane, In Roma, MDXCIII, Web, 28 June 2016. < http://www.asim.it/iconologia/ ICONOLOGIAview.asp?Id=103>; JAMES HALL (note 19), 131.

\section{2}

CESARE RIPA (note 21), (http://www.asim.it/iconologia/ICONOLOGIAview.asp?Id=140).

23

The order was founded in 1430 by Philip III the Good, Duke of Burgundy, with the primary aim of defending the Roman Catholic faith. After Mary of Burgundy, the sole heiress to the Duchy of Burgundy, married the Austrian archduke Maximilian in 1477, who was later crowned the King of the Germans (1486) and Holy Roman Emperor (1493), the position of the order's grand master passed to the House of Habsburg. See: PAUL J. BALFOUR, The Order of the Golden Fleece, in: The Scottish Historical Review, V/20 (1908), 405-410.

24

JAMES HALL (note 19), 108; SABINE POESCHEL, Handbuch der Ikonographie: sakrale und profane Themen der bildenden Kunst, Darmstadt, 2007, 328.

25

CESARE RIPA (note 21), (http://www.asim.it/iconologia/ICONOLOGIAview.asp? Id=103).

26

CESARE RIPA (note 21), (http://www.asim.it/iconologia/ICONOLOGIAview.asp?Id=46); JAMES HALL (note 19), 309.

27

In the original Hungarian edition of Zrínyi's book (1905), the reproduction is printed on a special piece of paper bound into the text block between pages sixty-four and sixty-five. In the new Croatian edition (2005), the reproduction is on page ninety-one. The same reproduction was published in: JOSIP HORVAT, Kultura Hrvata kroz 1000 godina [ 1000 years of Croatian culture], vol. 1, Zagreb, 1939, plate 120, no. 219. According to the description of the image, the original photograph was stored at the photographic archive of the weekly journal Svijet: ilustrirani tjednik (page 445).

28

MIRJANA REPANIĆ-BRAUN, Barokno slikarstvo u Hrvatskoj franjevačkoj provinciji sv. Ćirila i Metoda [Baroque painting in the Croatian Franciscan Province of St Cyril and St Methodius], Zagreb, 2004, 141; IVANA GOLENKO, Slikarska djela franjevačkog samostana sv. Nikole biskupa [Paintings from the Franciscan monastery of St Nicholas the Bishop], in: Franjevci u 
Čakovcu. Fotomonografija u povodu 350. obljetnice dolaska franjevaca u Čakovec, 1659.-2009., (ed.) Stjepan Hranjec, Čakovec, 2009, 199-203, 201, 211.

29

MIRJANA REPANIĆ-BRAUN (note 28), 141.

30

VLADIMIR MARKOVIĆ, Barokni dvorci Hrvatskog zagorja [Baroque mansions in Hrvatsko Zagorje], Zagreb, 1995, 8.

31

KÁROLY ZRÍNYI (note 3, 1905), 65-66.

32

At that point, Emperor Charles VI had no male heir; he had two daughters, Maria Theresa (b. 1717) and Maria Anna (b. 1718). Since his predecessor, Emperor Joseph I, had died without male offspring, the possibility that he would be succeeded by one of his daughters grew more probable.

33

For both versions, see: KÁROLY ZRÍNYI (note 3, 1905), 65-66.

34

It was precisely Michael Johann Althann III who annexed Medimurje to the Hungarian County of Zala in 1721. Međimurje remained under the Hungarian administration until the end of the First World War, except for a short period during the tenure of Viceroy Josip Jelačić (1848-1861), when it was part of the Kingdom of Croatia. See: VLADIMIR KALŠAN (note 7), 162, footnote 1.

35

KÁROLY ZRÍNYI (note 3, 1905), 66.

36

He interprets the female figure as the "Magyar nemzet" (Hungarian nation) and the male figure as the "leigázott magyarság" (subjugated Hungarians). See: KÁROLY ZRÎNYI (note 3, 1905), 66.

37

RUDOLF HORVAT (note 6, 1929), 335; IDEM (note 6, 1993), 200.

38

See note 34 .

39

IVANA JUKIĆ (note 6).

40

IVANA JUKIĆ (note 6), 309-310.

41

IVANA JUKIĆ (note 6), 310; STEFAN SEITSCHEK, Die Pragmatische Sanktion, in: 300 Jahre Karl VI., 1711-1740. Spuren der Herrschaft des "letzten" Habsburgers, (eds.) Michaela Follner, Stefan Seitschek, Vienna, 2011, 235-239, 237-238.

42

IVANA JUKIĆ (note 6), 311.

43

IVANA JUKIĆ (note 6), 312.

44

KÁROLY ZRÍNYI (note 3, 1905), 66.

45

FRIEDRICH POLLEROSS, From the exemplum virtutis to the Apotheosis: Hercules as an Identification Figure in Portraiture: An Example of the Adoption of Classical Forms of Representation, in: Iconography, propaganda, and legitimation, (ed.) Allan Ellenius, Oxford, 1998, 37-62, 37. I would like to thank Mr Friedrich Polleroß, $\mathrm{PhD}$ for his advice on the interpretation of the Čakovec painting and his articles on the Herculean topic, with which he kindly provided me.

46

FRIEDRICH POLLEROSS (note 45), 38. See also: JOACHIM BERGER, Herkules - Held zwischen Tugend und Hybris. Ein europäischer Erinnerungsort der Frühen Neuzeit?, in: Aufdem Weg nach Europa: Deutungen, Visionen, Wirklichkeiten, (eds.) Irene Dingel and Mathias Schnettger, Göttingen, 2010, 79-106, 85-86.

47 FRIEDRICH POLLEROSS (note 45), 40; SABRINE POESCHEL, (note 24), 329.

48

JOACHIM BERGER (note 46), 90-91.

49

FRIEDRICH POLLEROSS, Zur Repräsentation der Habsburger in der bildenden Kunst, in: Welt des Barock. Katalog zur Oberösterreichischen Landesausstellung 1986 im Augustiner-Chorherrenstift St. Florian, (ed.) Rupert Feuchtmüller, Vienna, 1986, 87-104, 102-103; FRIEDRICH POLLEROSS (note 45), 49.

50

In previous studies, the emperor's sculpture has been mostly attributed to the Austrian sculptor, architect, and painter Paul Strudel, but recent research suggests the statue was most probably executed by the court sculptor Antonio Corradini (1732-1736). The surrounding sculptures of Charles's ancestors were executed by Paul Strudel and his two brothers, Peter and Dominik (1695-1715), whereas the dome fresco was made by the court painter Daniel Gran (1726-1730). See: MONIKA WEBER, Das Standbild Kaiser Karls VI. im Prunksaal der Nationalbibliothek in Wien: ein neuentdecktes Werk des Venezianers Antonio Corradini, in: Zbornik za umetnostno zgodovino (Nova vrsta), 41 (2005), Ljubljana, 98-134.

51

The sculpture was executed by the Austrian sculptor Balthasar Permoser (1718-1721) and was placed at the Upper Belvedere in Vienna, where it is still on display. See: FRIEDRICH POLLEROSS (note 45), 61; GEORG LECHNER, Prince Eugene of Savoy: The Hercules and Apollo of His Time, in: Prince Eugene's Winter Palace, (ed.) Agnes Husslein-Arco, Vienna, 2013, 99-107, 102-103.

52

Althann built the Hall after the plans made by the court architect Johann Bernhard Fischer von Erlach. The sculptures of his ancestors were executed by Tobias Kracker and the fresco by Johann Michael Rottmayr. See: FRIEDRICH POLLEROSS, 'Virtutum exercita sunt gradus ad gloriam': Zum 'concetto' des Ahnensaales in Frain an der Thaya, in: Wiener Jahrbuch für Kunstgeschichte, 51 (1998), Wien, 105-114, 203-206.

53

BRIGITTE HEINZL, Die Freskomalerei Paul Trogers, in: Wiener Jahrbuch für Kunstgeschichte, 19 (1962), Vienna, 165-203, 172-173.

54

BRIGITTE HEINZL (note 53), 176-177.

55

BRIGITTE HEINZL (note 53), 176. Original text: "Wer zur Weisheit gelangen will, muß durch Fleiß und Arbeit die Laster ausrotten und die Tugenden in sich einpflanzen."

56

MLADEN OBAD-ŠĆITAROCI, Dvorci i perivoji Hrvatskoga zagorja [Castles, Manors and Gardens of Hrvatsko Zagorje], Zagreb, 1993, 208-210; ANDREJA GARDAŠANIĆ, Profano 
zidno slikarstvo sjeverozapadne Hrvatske u drugoj polovini XVIII stoljeća [Secular wall painting in north-western Croatia during the second half of the $18^{\text {th }}$ century] (MA thesis), Zagreb, 1994, vii, 7-8; DANICA PELKO, Iz povijesti Oroslavja [From the history of Oroslavje], in: Hrvatsko zagorje: časopis za kulturu Krapinsko-zagorske županije, 7/1 (2001), Donja Stubica, 32-38, 29-30; MIRJANA REPANIĆ BRAUN, Dvorac Donje Oroslavje: Zidne slike [Donje Oroslavje Mansion: Wall paintings], in: Umjetnička topografija $\mathrm{Hr}$ vatske: Krapinsko-zagorska županija, (ed.) Ivanka Reberski, Zagreb, 2008, 489-491, 489; MIRJANA REPANIĆ BRAUN, Pitanje stila u zidnom slikarstvu nakon 1750. na odabranim primjerima [The question of style in wall painting after 1750: selected examples], in: Zbornik radova znanstvenog skupa Klasicizam u Hrvatskoj, (ed.) Irena Kraševac, Zagreb, 2016, 265-281, 277.

57 MIRJANA REPANIĆ BRAUN (note 56, 2008), 489, 491; EADEM (note 56, 2016), 277.

58

BARBARA MUROVEC, Alegorija petih čutov v gradu Brežice [Allegory of the five senses in the Brežice Castle], in: Vita artis perennis: Ob osemdesetletnici akademika Emiljana Cevca, (ed.) Alenka Klemenc, Ljubljana, 2000, 403-408.

59

OLIVER MILLAR, The Whitehall Ceiling, in: The Burlington Magazine, 98/641 (1956), London, 258-265.

60

LISA ROSENTHAL, Gender, Politics and Allegory in the Art of Rubens, Cambridge et al., 2005, 106.

61

LISA ROSENTHAL (note 60), 108.

62

Apart from the already mentioned ceiling painting in Donje Oroslavje, other representative examples are the wall paintings from the Drašković Mansion in Brezovica (1776), the Oršić Mansion in Gornja Bistra (1778) and the Rattkay Mansion in Miljana (second half of the $18^{\text {th }}$ century). See: ANĐELA HORVAT, Barok u kontinentalnoj Hrvatskoj [Baroque in continental Croatia], in: Anđela Horvat, Radmila Matejčić, and Kruno Prijatelj, Barok $u$ Hrvatskoj, Zagreb, 1982, 3-381, 185-187.

\section{Sažetak}

\section{Maja Žvorc}

\section{Heraklovska alegorija u čakovečkom Starom gradu: naručitelj i kontekst}

U Muzeju Međimurja Čakovec, smještenome unutar palače Staroga grada, pohranjena je i izložena štafelajna slika koja prikazuje grčkoga heroja Herakla i boginju Atenu okružene personifikacijama vrlina i puttima kako se bore protiv nemejskoga lava. Slika je kopija freske koja je nekoć ukrašavala svod monumentalnog stubišta koje je povezivalo gornje katove palače, a izradio ju je i potpisao zasad malo poznati slikar Anton Maria Konrath 1797. godine. Svodna slika i stubište nastali su tijekom druge četvrtine 18. stoljeća kada je čakovečki Stari grad bio u posjedu grofice Anne Marije Althan (rođena Pignatelli de Belriguardo; Alcudia, 1689. - Beč, 1755.), dvorske dame i ljubavnice cara Karla VI. (hrvatsko-ugarski kralj kao Karlo III.; Beč, 1685.-1740.), koja je sveobuhvatnim radovima pretvorila tada zapuštenu palaču u reprezentativnu baroknu rezidenciju. Slika i stubište uništeni su sredinom 19. stoljeća kada je čakovečka palača prenamijenjena u tvornicu za preradu šećerne trske. Prema mišljenju povjesničara koji su se bavili interpretacijom slike (Karóly Zrínyi 1905.; Rudolf Horvat 1908., 1929.; Ivana Jukić 2014.), grofica Althan naručila je izradu navedene svodne slike kako bi ovjekovječila prigodu kada je uz pomoć dvoje svojih poznanika, grofice Eleonore Batthyány (rođena Starttmann; Pfalz?, 1672. - Beč, 1741.) i princa Eugena Savojskoga (Pariz, 1663. - Beč, 1736.), uspjela odgovoriti cara da izjednači Ugarsko Kraljevstvo s austrijskim nasljednim zemljama i prisili ugarsko plemstvo da prihvati Pragmatičku sankciju (1713.), propis kojim je car htio osigurati pravo nasljedstva ženskoj lozi habsburške dinastije. Prema njihovu mišljenju, grofica Althan odabrala je alegorijsko-mitološki prikaz borbe Herakla i Atene protiv nemejskoga lava koji simbolizira borbu carevih pobornika protiv dijela ugarskoga plemstva koji ne želi priznati Sankciju. S obzirom na to da navedena interpretacija nije osnovana na pisanom concettu ili neposrednim povijesnim dokumentima, sa sigurnošću možemo tvrditi samo da slika prikazuje borbu između vrlina (jakost, mudrost, sloga i čast) i mana. Tematski i kompozicijski slika prati korak sa suvremenim ostvarenjima u europskoj likovnoj umjetnosti. Obje vrste poveznica mogu se pronaći u opusu Paula Trogera (Zell unter Welsberg, 1698. - Beč, 1762.), točnije u njegovom osliku svoda Mramorne dvorane (Marmorsaal) benediktinske opatije u Melku (1731.) i knjižnice cistercitske opatije u Zwettlu (1732./1733.). Slično rješenje impostacije Heraklova lika može se uočiti i na svodnom osliku glavne dvorane dvorca Vojković-Vojkffy u Donjem Oroslavju (1790-e) te osliku svoda reprezentativnog stubišta dvorca u Brežicama (oko 1718.) koji je izveo Johann Caspar Waginger. Moguće je da je likovni izvor rješenja Heraklove impostacije slika Pietera Paula Rubensa (Siegen, 1577. - Antwerpen, 1640.) koja krasi strop dvorane za bankete (Banqueting House) palače Whitehall u Londonu, koja je zahvaljujući Christoffelu Jegheru prenesena u grafički medij.

Ključne riječi: obitelj Althan, Stari grad Čakovec, zidno slikarstvo, alegorija, Anton Maria Konrath, Karlo VI. (III.), Pragmatička sankcija 